\title{
Optimization of Phosphoric fertilizers for Cultivation of Potato under high Phosphorus Soils of Eastern Indo-Gangetic Plains of Bihar
}

\author{
SARALA YADAV ${ }^{1 *}$, MANOJ KUMAR ${ }^{2}$ AND $S$ K YADAV ${ }^{3}$
}

\begin{abstract}
Phosphorus $(\mathrm{P})$ is an important element that is applied in the form of di-ammonium phosphate or single super phosphate in potatoes. An experiment was conducted at ICAR-Central Potato Research Station, Patna, Bihar during Rabi, 2017-18 and 2018-19 to evaluate invariably use of phosphorus fertilizers in potato crop. The use of phosphorus is often applied at higher rate than its uptake from the soil. Therefore, experiment was undertaken with the objective to optimize and utilize soil phosphorus more efficiently. Potato variety Kufri Khyati was planted in three replications with eight different treatments of fertilizer phosphorus. Data on tuber yield $(\mathrm{t} / \mathrm{ha})$ and tuber number (lacs/ha) was recorded. The maximum tubers were recorded at $20 \%$ of recommended dose of phosphorus i.e. 5.14 lacs/ha followed by $100 \%$ recommended dose of phosphorus (4.56 lacs/ha). The tuber yield was maximum at $100 \%$ recommended dose of phosphorus ( $33.53 \mathrm{t} / \mathrm{ha}$ ) followed by $50 \%$ recommended dose of phosphorus ( $31.35 \mathrm{t} / \mathrm{ha}$ ), which was at par with the yield obtained at $20 \%$ (30.29 t/ha) to $40 \%$ (29.98 t/ha) of recommended dose of phosphorus. The recorded results showed that the omission of phosphorus does not have any significant reduction in the yield as compare to tuber numbers. Therefore, it may be recommended that in high $\mathrm{P}$ soils, the maintenance dose of $20 \%$ of recommended dose of $\mathrm{P}$ is sufficient to harvest economic yield.
\end{abstract}

KEYwORDS

Kufri Khyati, Phosphorus, Recommended dose, Tuber number, Tuber yield

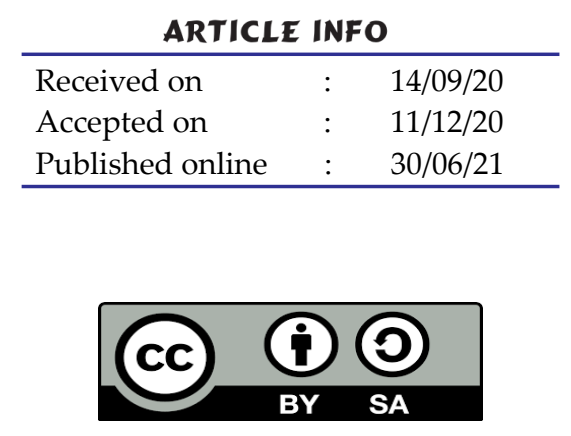

\section{INTRODUCTION}

$\mathrm{P}$ otato is most important tuberous vegetable it ranks fourth among the important crops i.e. rice, wheat and maize (Singh et al (2013). India is second largest producer of potato after China in terms of production statistics. This is most important vegetable cash crop grown all over country, plays a significant role in improving food security. Bihar is one of the major potato producing state in India (Bharati et al, 2014). It is rich in vitamin C, B1, $\mathrm{B} 2$ and B6 and minerals such as potassium, phosphorous and magnesium and a good source of high-quality protein (Kahsay, 2019). It is short duration crop with high yield potential as compare to other crops and vegetables (Yadav et al, 2020). The important nutrients required for its cultivation are nitrogen, phosphorus and potassium applied at the recommended rate of 180:80:100 in the form of urea, diammonium phosphate or single super phosphate and murate of potash (Zewide et al, 2012). Phosphorus is the second most important macro-nutrient limiting plant growth after nitrogen in most soils. It is a plant nutrient that intervenes in cellular energy transfer, photosynthesis and respiration. It is also an important component of nucleic acid nucleotides, phospholipids and phosphorylated sugars (Wc and Carswell 1999 and Marschner 1996). Adequate phos- phorus nutrition enhances many aspects of plant physiology, including the fundamental processes of photosynthesis, root growth particularly, the development of lateral roots and fibrous rootlets (Brady and Weil, 2008). Despite the abovementioned importance of the crop, the productivity of potato is around 15-20 $\mathrm{t} / \mathrm{ha}$. Lack of appropriate agronomic practices and excessive use of fertilizers adversely affect the production and productivity of potato and high cost of cultivation. The potato crop normally removes approximately $20 \mathrm{~kg}$ of phosphorus per hectare from the soil. Whereas, application of $\mathrm{P}_{2} \mathrm{O}_{5}$ is generally done in the range of $60-80 \mathrm{~kg} / \mathrm{ha}$. This type of practice leads to the building of high $\mathrm{P}$ in the soils. The objective of the experiment was to workout possibility of saving $\mathrm{P}$ fertilizer in the soils having high available $\mathrm{P}$. The ferilizer P in the soils of Eastern Indo-Gangetic plains of Bihar is $88 \mathrm{~kg} / \mathrm{ha}$. Hence, the use of appropriate and judicious management of phosphorus fertilizer can boost the production and productivity of the potato with judicious use of chemical fertilizers.

\section{MATERIALS AND METHODS}

The field experiment was carried out during the years 2017-18 and 2018-19 at ICAR- Central Potato Research Station, Patna, Bihar. The potato variety Kufri Khyati was planted in the

\footnotetext{
1 Scientist, Central Potato Research Station, Bihar, Patna, India

2 Director (Acting), Central Potato Research Institute, Shimla, Himachal Pradesh, India

3 Scientist, ICAR-Indian Institute of Sugarcane Research, Lucknow, Uttar Pradesh, India

*Corresponding author email: sarlayadavbhu@gmail.com
} 
first week of November as timely sown main crop for this experiment (Figure 1). The texture of soil of experimental plot was sandy loam having high availability of phosphorus. The experiment was carried out with eight treatments in randomized block design in three replications. The different levels of phosphorus in the form of DAP (Di-ammonium Phosphate) were applied as treatment for the experiment viz, T1 (0 Phosphorus), T2 (0 Phosphorus + FYM), T3 (10\% P of recommended dose), T4 (20\% $\mathrm{P}$ of recommended dose), T5 (30\% P of recommended dose), T6 (40\% P of recommended dose), T7 (50\% P of recommended dose), T8 (100\% P of recommended dose). The other fertilizers such as nitrogen and potassium were applied at the rate of recommended doses such as 180 and $100 \mathrm{~kg} / \mathrm{ha}$ in the form of urea and murate of potash respectively. The $1 / 2 \mathrm{~N}: \mathrm{P}: \mathrm{K}$ was applied as a basal dose at the time of land preparation. Soil samples collected from 10 different random locations before fertilizer application and also after harvest of crop, were analyzed. Germination count was done, 10 days after planting of the crop and accordingly percentage was calculated. The no. of shoots per plant was recorded 25-30 days after planting during earthing up operation of crop, from five randomly selected plants in each replication of the different treatments. Harvesting of tubers were carried out (Figure 2), were graded in to four grades i.e. large (>80g), medium (51-80 g), small (31-50 g) and very small $(<30 \mathrm{~g})$. The tuber yield was recorded and calculated in tonnes per hectare. Tuber numbers were also calculated and converted in to lakhs per hectare. All the observations were recorded for different characters were statistically analyzed by using standard method suggested by Panse and Sukhatame (1978). the estimated values of the treatments and standard error variance were compared with fisher and Yates $\mathrm{F}$ table at 5 percent level of significance. The level of significance was tested against C.D. at 5 percent probability.

\section{RESULTS AND DISCUSSION}

Effect of phosphorus on plant growth and its attributes
Phosphorus plays important role in plant growth and development. The important growth attributes were germination percentage, number of shoots per plant and plant height etc. The pooled data of plant growth and its attributes over four years is presented in the Table 1 . The germination percentage was observed highest in the treatment $100 \%$ recommended dose of phosphorus application followed by $50 \%$ of recommended dose of phosphorus. In case of other doses i.e. $10 \%$, $20 \%, 30 \%, 40 \%$ of recommended dose of phosphorus, there is non-significant difference in the germination percentage were recorded. Whereas, there is significant difference in the germination percentage at zero level of phosphorus application as compare to the treatments containing phosphorus. The no. of shoots per plant were maximum at the $30 \%$ of recommended dose of phosphorus followed by $100 \%$ of recommended dose of phosphorus. The treatment levels $10 \%$ to $100 \%$ of recommended dose of phosphorus were having at par for the number of shoots per plant. The Plant height in general increased with the advancement in crop age irrespective of the treatment and reached maximum at maturity. The rate of increase in plant height were more during 30 to 60 DAP as compared to 60 DAP to maturity. The height of plants was almost ceased or slightly declined at maturity because of senescence. The plant height varied significantly among the different phosphorus doses during all growth stages due to positive effect of phosphorus (Gaur et al, 2017). At all growth stages, significantly tallest plant $(48.50 \mathrm{~cm})$ was noted under $100 \%$ of recommended dose of phosphorus at final stage and it was at par with all treatment levels including control (45.70 $\mathrm{cm})$. Lowest plant height was recorded in control treatment, which was lower than remaining treatments at all the stages at final stage. This may be due unavailability of nutrients to the plants required for plant growth and development. The increased availability of nutrients to the plants in balanced proportion resulting in higher uptake of nutrients, which ultimately resulted in higher plant height (Table 1 ).

Table 1: Plant growth attributes of potato (pooled over four years)

\begin{tabular}{lccc}
\hline Treatments & Germination (\%) & No. of shoots per plant & Plant height(cm) \\
Minus P (Control)-(T1) & 95.28 & 3.51 & 45.70 \\
Minus P (Control)+ FYM-(T2) & 96.57 & 3.55 & 45.78 \\
$10 \%$ of recommended dose of P-(T3) & 97.40 & 4.24 & 46.40 \\
$20 \%$ of recommended dose of P-(T4) & 97.54 & 4.60 & 47.50 \\
$30 \%$ of recommended dose of P-(T5) & 97.53 & 4.83 & 47.76 \\
$40 \%$ of recommended dose of P-(T6) & 98.20 & 4.55 & 47.80 \\
$50 \%$ of recommended dose of P-(T7) & 98.45 & 4.67 & 48.00 \\
$100 \%$ of recommended dose of P-(T8) & 98.55 & 4.82 & 48.50 \\
SE+_ & 0.81 & 0.20 & 2.50 \\
CD $(5 \%)$ & 1.78 & 0.80 & 7.62 \\
\hline
\end{tabular}




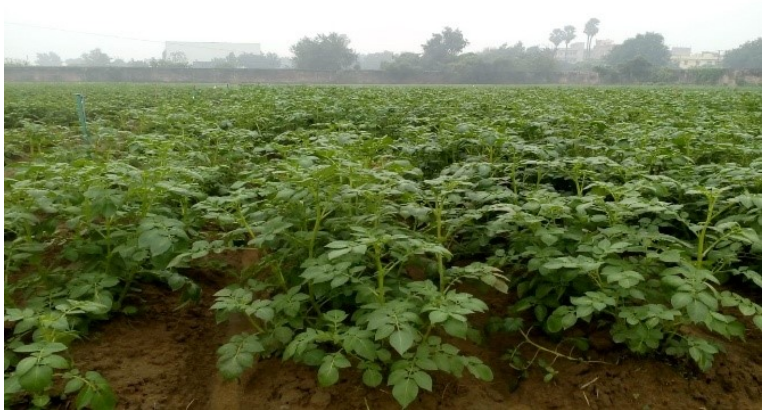

Fig. 1: Planting of potato variety K. Khyati

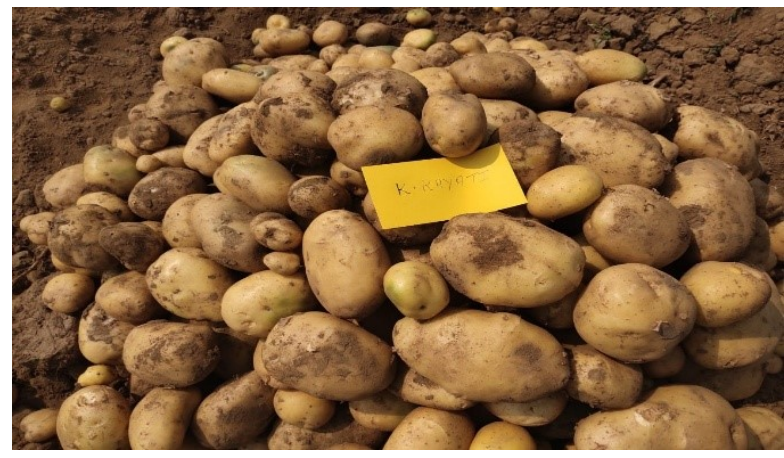

Fig. 2: Harvesting of the tubers of potato

\section{Effect of phosphorus on tuber yield and tuber numbers.}

The tuber yield (33.53 t/ha) was maximum at $100 \%$ of recommended dose of phosphorus which was at par with 40\% (29.98 t/ha) and 50\% (31.35 t/ha) of recommended dose of phosphorus. The numbers and yield of small tubers increased as the dose of $\mathrm{P}$ was increased, indicating that $\mathrm{P}$ may play an important role in regulating the number of tubers per plant (Rosen and Bierman, 2008).

In the present experiment the tuber yield was maximum for the $100 \%$ recommended dose of phosphorus followed by the yield obtained at $50 \%$ recommended dose of phosphorus. The following treatments viz. $20 \%, 30 \%, 40 \%, 50 \%$ and $100 \%$ of recommended dose of phosphorus were at par for the tuber yield. However when no phosphorus was applied then there was significant reduction in yield. This indicated that in high $P$ soils, it is required to supply a minimum maintenance dose of $20 \%$ of recommended dose of $\mathrm{P}$ for obtaining economic production of potato (Table 2 ).
Table 2: Effect of different Phosphorus levels on tuber yield and numbers of the potato variety Kufri Khyati (pooled over four years)

$\begin{array}{lcc}\text { Treatments } & \begin{array}{c}\text { Yield } \\ \text { (t/ha) }\end{array} & \begin{array}{c}\text { Tuber Nos. } \\ \text { (lacs/ha) }\end{array} \\ \text { Minus P (Control) -(T1) } & 24.57 & 4.02 \\ \text { Minus P (Control)+ FYM -(T2) } & 25.95 & 4.27 \\ \text { 10\% of recommended dose of } & 29.40 & 4.33 \\ \text { P- (T3) } & & \\ \text { 20\% of recommended dose of } & 30.29 & 5.14 \\ \text { P -(T4) } & & \\ \text { 30\% of recommended dose of } & 29.30 & 4.19 \\ \text { P -(T5) } & & \\ \text { 40\% of recommended dose of } & 29.98 & 4.41 \\ \text { P -(T6) } & & \\ \text { 50\% of recommended dose of } & 31.35 & 4.37 \\ \text { P -(T7) } & & 4.56 \\ \text { 100\% of recommended dose of } & 33.53 & \\ \text { P -(T8) } & & - \\ \text { CD at } 0.05 & 4.09 & \end{array}$

Phosphorus fertilizer application increased total tuber yield and yield of undersized tubers (tubers less than 30g), but decreased the proportion of large-sized tubers (greater than $85 \mathrm{~g}$ ). Due to the increase in small, unmarketable tubers, $\mathrm{P}$ fertilizer application did not have a significant effect on marketable tuber yield (tubers of $30-85 \mathrm{~g}$ ). The total number of tubers per plant and the number of undersized tubers were also higher and the number of large tubers was lower, when $\mathrm{P}$ was applied compared with the zero P i.e. control. (Rosen and Bierman, 2008). Maximum number of tubers were recorded at $20 \%$ of recommended dose of phosphorus (5.14 lac/ha) followed by $100 \%$ of recommended dose of phosphorus i.e. 4.56 lac/ha (Table 2 ).

\section{CONCLUSION}

Potato is one of the most important widely cultivated tuberous vegetable crops of India as well as world. Yield and productivity of potato in Eastern Indo-Gangetic plains of Bihar are below the national average. Among different factors, soil fertility and nutrient management are the key factors affecting crop productivity and soil nutrient depletion. To enhance the productivity of potato soil fertility management has to be the primary role of the producers. Different experiments conducted showed that application of nutrient has a positive relation to producing a higher yield of potato. The experiments confirmed that adequate application of phosphorus increases the production of potato. Therefore, application of adequate nutrient is the only option to maximize production and productivity of potato in the soils where potato-based cropping system is being followed from several years and soils have become rich in available $\mathrm{P}$. There is great possibility of saving 
$80 \%$ of $\mathrm{P}$ fertilizers. To avoid any significant reduction in yield an application of maintenance dose i.e. $20 \%$ of recommended

\section{REFERENCES}

Bharati RC, Singh KM, Singh CN and K A. 2014. Economic condition of eastern region of India -An statistical evaluation. Journal of AgriSearch 1(3): 173-179.

Brady NC and Weil RR 2008. The nature and properties of soils. 14th Edition. Pearson Education International (Upper Saddle River, New Jersey. 975p: Macmillan Publishing Co. Inc).

Gaur D, Singh SP, Sharma K, Sharma SK, Dhakad H, Singh R, Dangi RP, Sharma R, Dixit JP, Rawat GS and Rai AK. 2017. Effect of different phosphorus levels on growth attributes physiological parameter and grading of tuber in potato crop. Solanum tuberosum L.) International Journal of Chemical studies 5(6):215219.

Kahsay WS. 2019. Effects of nitrogen and phosphorus on potatoes production in Ethiopia: A review. Cogent Food $\mathcal{E}$ Agriculture 5(1):1572985-1572985. url: https://dx.doi.org/10.1080/ 23311932.2019.1572985. doi: 10.1080/23311932.2019.1572985

Marschner H 1996. Mineral nutrition of higher plants (London, England: Academic press).

Rosen CJ and Bierman PM. 2008. Potato Yield and Tuber Set as Affected by Phosphorus Fertilization. American Journal of Potato Research 85(2):110-120. url: https://dx.doi.org/10.1007/ dose of P should be applied.

s12230-008-9001-y. doi: 10.1007/s12230-008-9001-y

Singh AK, Singh KA, Bharati RC and Chandra N. 2013. Response of intercrops and nutrient management on the performance of tobacco based intercropping system and assessment of system sustainability. Bangladesh Journal of Botany 42(2):343-348. url: https://dx.doi.org/10.3329/bjb.v42i2.18040. doi: 10.3329/ bjb.v42i2.18040

Wc P and Carswell MC 1999. Plant response to environmental stress: from phytohormones to genome reorganization, ed. Lerner and R. H. (New York, NY, USA: Marcel-Dekker), 350-372.

Yadav SK, Singh RK, Singh SK, Yadav S and Bakade RR. 2020. Site specific nutrient management in potato through nutrient omission plot technique. Journal of AgriSearch 6(02):59-62. url: https: //dx.doi.org/10.21921/jas.v6i02.18098. doi: 10.21921/jas.v6i02. 18098

Zewide I, Mohammed A and Tulu S. 2012. Effect of Different Rates of Nitrogen and Phosphorus on Yield and Yield Components of Potato (Solanum tuberosum L.) at Masha District, Southwestern Ethiopia. International Journal of Soil Science 7(4):146-156. url: https://dx.doi.org/10.3923/ijss.2012.146.156. doi: 10.3923/ ijss.2012.146.156

Citation:

Yadav S, Kumar M and Yadav SK. 2021. Optimization of Phosphoric fertilizers for Cultivation of Potato under high Phosphorus Soils of Eastern Indo-Gangetic Plains of Bihar. Journal of AgriSearch 8(2): 79-82 